\title{
ANALISIS KUALITAS PELAYANAN PUBLIK DALAM PEMBUATAN KARTU TANDA PENDUDUK ELEKTRONIK (E-KTP) DI DINAS KEPENDUDUKAN DAN PENCATATAN SIPIL KOTA TERNATE
}

\author{
Zainal Muksin
}

zainal.umj@gmail.com

STISIPOL P12

\begin{abstract}
ABSTRAK
Penelitian ini bertujuan untuk menganalisis kualitas pelayanan publik dalam pembuatan e-KTP di Dinas Kependudukan dan Pencatatan Sipil Kota Ternate. Metode penelitian ini adalah deskriptif dengan menggunakan desain kualitatif. Penelitian deskriptif kualitatif merupakan penelitian yang bertujuan untuk menggambarkan dan mendiskripsikan peristiwa maupun fenomena yang terjadi di lapangan dan menyajikan data secara sistematis, faktual, dan akurat. Pegumpulan data pada penelitian ini dilakukan dengan teknik observasi, wawancara, dan dokumentasi. Pada penelitian ini Penulis menggunakan triangulasi sumber untuk mengecek keabsahan data penelitian. Analisis data dalam penelitian ini menggunakan empat komponen yang terdiri dari pengumpulan data, reduksi data, sajian data, dan penarikan kesimpulan. Hasil penelitian menunjukan bahwa kualitas pelayanan publik dalam pembuatan e-KTP di Dinas Kependudukan dan Pencatatan Sipil Kota Ternate diukur dari lima indikator berdasarkan teori yang dikemukakan oleh Zeithalm (1990), diantaranya adalah dimensi tangible, realibility, responsiviness, assurance, dan emphaty, maka kualitas pelayanan e-KTP dikatakan masih buruk. Hal ini ditandai terdapat banyak kendala terhadap pelayanan e-KTP yang diberikan kepada masyarakat sebagai pengguna layanan. diantaranya adalah kondisi infrastruktur bangunan yang tidak layak, kurangnya fasilitas penunjang dalam pelayanan e-KTP, kurangnya perawatan terhadap fasilitas penunjang, ketidak nyamanan tempat pelayanan, penampilan petugas yang tidak seragam, rendahnya kedisiplinan petugas layanan, adanya praktek diskriminasi dalam pelayanan, dan kurangnya sumber daya manusia (petugas layanan).
\end{abstract}

Kata kunci : Kualitas Pelayanan e-KTP

\begin{abstract}
This study aims to find out (1) the quality of publik services in the making of Electronic Identity Card (e-KTP) in the Population and Civil Registration Office of Ternate City, (2) factors affecting the Electronic Identity Card (e-KTP) service of the Department of Population and Civil Registration in Ternate. The type of this research is descriptive by using qualitative method. Descriptive qualitative research is a research that aims to describe events and phenomena that occur in the field and presents data in a systematic, factual, and accurate. Data collection in this research is done by observation, interview, and documentation. In this study the author uses triangulation of sources to check the validity of research data. Data analysis in this study using four components consisting of data collection, data reduction, data presentation, and conclusion. The result of the research shows that the quality of Electronic Identity Card (e-KTP) making service in the Department of Population and Civil Registration of Ternate is measured from five indicators such as tangible dimension, realibility, responsiveness, assurance and emphaty have been applied well but have not maximal. This is indicated that the services provided are not in accordance with the expectations of the community such as the condition of improper building infrastructure, lack of supporting facilities in Electronic Identity Card (e-KTP) service, service discomfort, lack of discipline by service personnel, stil have discrimination in service, and lack of human resources (service personnel).
\end{abstract}

Keywords: Quality of Electronic Identity Card (e-KTP) Service. 


\section{PENDAHULUAN}

Pada dasarnya wacana tentang pelayanan publik menjadi perhatian yang sangat urgen, karena pelayanan publik (publik service) merupakan hak yang mendasar bagi setiap Warga Negara dan kewajiban bagi Negara untuk menyelenggarakannya. Dari prespektif yuridis telah termaktub dalam Undang-Undang Dasar tahun 1945 (alenia ke-4) bahwa "kemudian dari pada itu untuk membentuk suatu pemerintah Negara Indonesia yang melindungi segenap bangsa Indonesia, dan seluruh tumpah darah Indonesia, dan untuk memajukan kesejahteraan umum, mencerdaskan kehidupan bangsa, dan ikut melaksanakan ketertiban dunia"

Publik service secara regulasi telah di perjelas dalam Undang-Undang Nomor 25 Tahun 2009 (Pasal 5) tentang Pelayanan Publik, bahwa Pelayanan publik adalah kegiatan atau rangkaian kegiatan dalam rangka pemenuhan kebutuhan pelayanan sesuai dengan peraturan perundangundangan bagi setiap Warga Negara dan penduduk atas barang, jasa, dan/atau pelayanan administratif yang disediakan oleh penyelenggara pelayanan publik.

Potret pelayanan publik di Indonesia dari masa ke masa mengalami fluktuatif. Berdasarkan data dikeluarkan oleh lembaga Ombudsman Republik Indonesia sebagai lembaga yang memiliki kewenangan mengawasi penyelenggaran pelayanan publik yang diselenggarakan oleh Penyelenggara Negara, ternyata putugas pelayanan public utamanya di daerah-daerah masih memiliki banyak kelemahan. Pelayanan publik yang diberikan oleh pemerintahan daerah belum memberikan kepastian jaminan dengan baik, dan pelayanan publik di Indonesia masih banyak basa-basinya. (http://ombudsman.go.id).

Pada kondisi tersebut tentu akan muncul presepsi di masyarakat bahwa Negara dengan pemerintahannya belum mampuh memaksimalkan proses penyelenggaraan pelayanan publik yang berkualitas sehingga memunculkan ketidakpercayaan masyarakat kepada pemerintah. Kalau sudah terjadi keadaan seperti ini maka bisa dikatakan Negara telah gagal dalam menjalankan tugas dan fungsinya sesuai dengan apa yang di amanatkan oleh UUD 1945.

Permasalahan terkait pelayanan publik dapat dilihat juga pada realitas di lapangan terutama pada instansi pemerintah yang secara langsung memberikan pelayanan publik. Praktek-praktek Korupsi Kolusi dan Nepotisme (KKN) yang berbentuk perilaku penyimpangan dalam pelayanan publik masih sering terjadi (Kumorotomo dalam Dwiyanto, 2008:99). Hal sedemikian ini akan berdampak pada terjadinya diskriminasi pelayanan dan pemberian uang yang semakin merajalela di sektor pelaksana pelayanan sebagai uang stimulus untuk penyelesaian secara cepat apa yang dibutuhkan masyarakat sehingga menimbulkan citra buruk terhadap kualitas layanan publik.

Pelayanan pembuatan e-KTP merupakan salah satu contoh bentuk pelayanan publik yang diberikan oleh aparatur pemerintah. Keberadaan e-KTP ini dilatarbelakangi oleh sistem pembuatan KTP konvensional di Indonesia yang memungkinkan seseorang dapat memiliki lebih dari satu KTP. Hal ini disebabkan belum adanya basis data terpadu yang menghimpun data penduduk dari seluruh Indonesia. Fakta tersebut memberi peluang penduduk yang ingin berbuat curang terhadap Negara dengan menduplikasi KTP-nya.

Pada skala nasional pembuatan e-KTP dinyatakan masih banyak terdapat banyak kelemahan. Bahkan kasus yang kembali terungkap dipermukaan bahwa terjadi korupsi e-KTP secara besar-besaran oleh oknum-oknom pejabat Negara. Proyek pengadaan e-KTP yang digulirkan oleh Kementrian Dalam Negeri pada tahun 2011 kemaren menggunakan dana sebesar Rp 5,9 trilliun untuk membiayai proyek ini. Belakangan ini dengan diketahui bahwa telah dikorupsi sebesar Rp 2,3 trilliun. Dengan nominal angka yang dikorupsi terkait dengan dana e-KTP ini maka dapat dikatakan bahwa ini merupakan kasus korupsi yang terbesar Indonesia (http://www.sketsanews.com).

Sementara di daerah-daerah berdasarkan data yang dirilis oleh Ombudsman dalam (http://www.antarakepri.com) bahwa dalam implementasi pembuatan e-KTP sebagai transisi dari KTP non elektronik masih terdapat banyak masalah. hal ini ditandai dengan adanya praktek percaloan (pungutan liar) terhadap masyarakat, terdapat praktek maladministrasi, sistem jemput bola untuk mendorong percepatan layanan e-KTP tidak dilakukan, dan ketidaksesuaian jumlah blangko untuk penduduk yang belum terlayani e-KTP.

Dinas Kependudukan dan Pencatatan Sipil Kota Ternate adalah Dinas yang berwewenang menyelenggaraan administrasi kependudukan dalam pembuatan Kartu Tanda Penduduk Elektronik (e-KTP). DISDUKCAPIL terhadap mengimplementasikan tugas pelayanan dalam kepengurusan e-KTP di Kota Ternate sudah mengalami kemajuan yang signifikan dalam proses pelayanannya. Hal ini dilihat data yang diperoleh dari Ombudsman Maluku Utara bahwa DISDUCAPIL kota Ternate memiliki tingkat kepatuhan pelayanan publik yang baik atau masuk pada kategori zona hijau. Artinya bahwa kualitas pelayanan yang diberikan kepada masyarakat dalam pengurusan administrasi sudah cukup baik. 
Meskipun sudah digelari dengan predikat seperti itu ternyata DISDUKCAPIL Kota Ternate juga masih banyak mengalami kendala dalam melakukan pelayanan publik kepada masyarakat. Menurut bapak ismail (19 januari 2017) "bahwa pelayanan e-KTP di tahun sebelumnya memang masih sangat kacau dan amburadul, Hal itu di tunjukan dengan banyaknya keluhan dari masyarakat bahwa pelayanan yang diberikan masih berbelit-belit, masalah kedisiplinan pegawai, minimnya fasilitas pelayanan dengan ketidaktersediaan kursi yang maksimal di ruang tunggu, tidak ada ketepatan waktu pelayanan, masih adanya praktek diskriminatif dalam proses pelayanan e-KTP, dan berbagai masalah yang muncul. Namun di tahun 2015 hingga sekarang DISDUKCAPIL kemudian melakukan perbaikan dalam meningkatkan kualiatas pelayanan terhadap pembutan e-KTP sehingga terjadi perubahan yang signifikan sampai sekarang

Oleh sebab itu antara yang tertulis atau yang telah ditetapkan berbeda dengan kenyataan di lapangan. Kondisi ini tentu perlu adanya peningkatan kualitas pelayanan publik dalam beberapa hal terkait dengan pelayanan e-KTP. Hal ini yang mendorong dilakukannya penelitian tentang: "Analisis Pelayanan e-KTP" Study tentang: kualitas pelayanan dan faktor yang mempengaruhi pembuatan e-KTP Oleh DISDUKCAPIL Kota Ternate".

Tujuan penelitian ini untuk mengetahui dan menganalisis pembuatan e-KTP oleh DISDUKCAPIL Kota Ternate. Dan Untuk mengetahui dan menganalisis faktor pendukung dan penghambat dalam pelaksanaan pelayanan e-KTP oleh DISDUKCAPIL Kota Ternate.

\section{Konsep Pelayanan}

Pada konsep pelayanan ada dua kata yang sering disamakan dengan kata pelayanan (service) yaitu jasa dan layanan. Sebagai jasa maka service adalah keluaran berupa produk bukan barang atau tidak berwujud fisik yang diberikan atau yang didapat. Sebagai contoh adalah jasa pendidikan, jasa kesehatan, jasa transportasi, dan lain-lain. Sementara service mengandung makna melakukan sesuatu oleh pihak tertentu kepada pihak lain baik secara individu, kelompok, maupun secara organisasional (Ulber Silalahi, 2015:14)

Siagian dalam Hardiyansyah (2011:10) mengatakan bahwa pemerintahan dalam Negara pada hakikatnya menyelenggarakan dua jenis fungsi utama, yaitu fungsi pengaturan dan fungsi pelayanan. Fungsi pengaturan biasanya dikaitkan dengan hakikat negara modern sebagai suatu negara hukum (legal state), sedangkan fungsi pelayanan dikaitkan dengan hakikat
Negara sebagai suatu Negara kesejahteraan (welfare state). Baik fungsi pengaturan maupun fungsi pelayanan menyangkut semua segi kehidupan dalam penghidupan bermasyarakat, berbangsa dan bernegara, dan pelaksanaannya dipercayakan pada aparatur pemerintahan tertentu yang secara fungsional bertanggung jawab atas bidang-bidang tertentu kedua fungsi tersebut. Berkaitan dengan ini, Sinambela (2010:3) menjelaskan bahwa pada dasarnya manusia membutuhkan pelayanan, bahkan secara ekstrim dapat dikatakan bahwa pelayanan tidak dapat dipisahkan dengan kehidupan manusia.

Olehnya itu berangkat dari penjelasan diatas maka pelayanan sebagai proses pemenuhan kebutuhan melalui aktivitas orang lain secara langsung, merupakan konsep yang senantiasa aktual dalam berbagai aspek kelembagaan. Bukan hanya pada organisasi bisnis, tetapi telah berkembang lebih luas. Maka pelayanan adalah sebuah kegiatan atau aktifitas yang diberikan oleh penyedia pelayanan kepada objek yang dilayani untuk memfasilitasi dan memediasi mereka dalam memenuhi keperluan mereka. Dalam pelayanan (service) tentu diperlukan performance yang maksimal berupa sikap, perilaku, dan tindakan yang ditampilkan ketika memberikan layanan baik itu berupa pelayanan barang maupun pelayanan jasa.

\section{Konsep Publik}

Publik merupakan kata serapan yang berasal dari bahasa Inggris "publik", bahasa ini sudah digunakan oleh masyarakat bangsa Indonesia yang menyatakan bahwa publik ini diidentikan dengan masyarakat. Kata masyarakat ini dalam pengertian umum menyatakan semua kalangan umum yang ditujukan pada keseluruhan masyarakat Sugandi (2011:5). Pendapat tersebut Senada dengan Sugandi (2002:52) bahwa publik diartikan sebagai masyarakat, tetapi penggunaan kata publik dipertahankan untuk memudahkan dan membedakan dengan istilah masa dan kerumunan, meskipun perbedan itu sangat tipis.

Pengertian lain di sampaikan oleh Inu Kencana Syafi'ie et all (1999:18) publik adalah sejumlah manusia yang memiliki keseragaman berpikir, perasaan, harapan, sikap, dan tindakan yang benar dan baik berdasarkan nilai-nilai norma yang mereka miliki. Sedangkan Abdurrahman (1995:28) menguraikan bahwa publik merupakan sekelompok orang yang menaruh perhatian pada suatu hal yang sama. Publik dapat merupakan kelompok kecil, terdiri atas orang-orang dengan jumlah sedikit, juga dapat merupakan kelompok besar. Biasanya individu-individu yang termasuk ke dalam kelompok itu mempunyai solidaritas kepada kelompoknya, walaupun tidak terikat oleh struktur yang nyata, tidak berada pada suatu tempat atau ruang, atau tidak mempunyai hubungan langsung. 


\section{Konsep Publik}

Publik merupakan kata serapan yang berasal dari bahasa Inggris "publik", bahasa ini sudah digunakan oleh masyarakat bangsa Indonesia yang menyatakan bahwa publik ini diidentikan dengan masyarakat. Kata masyarakat ini dalam pengertian umum menyatakan semua kalangan umum yang ditujukan pada keseluruhan masyarakat Sugandi (2011:5). Pendapat tersebut Senada dengan Sugandi (2002:52) bahwa publik diartikan sebagai masyarakat, tetapi penggunaan kata publik dipertahankan untuk memudahkan dan membedakan dengan istilah masa dan kerumunan, meskipun perbedan itu sangat tipis.

Pengertian lain di sampaikan oleh Inu Kencana Syafi'ie et all (1999:18) publik adalah sejumlah manusia yang memiliki keseragaman berpikir, perasaan, harapan, sikap, dan tindakan yang benar dan baik berdasarkan nilai-nilai norma yang mereka miliki. Sedangkan Abdurrahman (1995:28) menguraikan bahwa publik merupakan sekelompok orang yang menaruh perhatian pada suatu hal yang sama. Publik dapat merupakan kelompok kecil, terdiri atas orang-orang dengan jumlah sedikit, juga dapat merupakan kelompok besar. Biasanya individuindividu yang termasuk ke dalam kelompok itu mempunyai solidaritas kepada kelompoknya, walaupun tidak terikat oleh struktur yang nyata, tidak berada pada suatu tempat atau ruang, atau tidak mempunyai hubungan langsung.

\section{Konsep Pelayanan Publik}

Hardiyansyah (2011:14) menjelaskan bahwa Pelayanan publik (publik service) oleh birokrasi publik merupakan salah satu perwujudan dari fungsi aparatur Negara sebagai abdi masyarakat di samping sebagai abdi Negara. Pelayanan publik dimaksudkan untuk mensejahterakan masyarakat (warga negara) dari suatu negara kesejahteraan (welfare state). Pendapat lain menurut pendapat Ahmad Ainur Rohman, At all (2010:3) Pelayanan publik adalah segala kegiatan dalam rangka pemenuhan kebutuhan dasar sesuai dengan hak-hak dasar setiap warga negara dan penduduk atau suatu barang, jasa, dan atau pelayanan administrasi yang disesuaikan oleh penyelenggara pelayanan yang terkait dengan kepentingan publik.

Berdasarkan pengertian-pengertian diatas maka dapat diartikan bahwa pelayanan publik merupakan suatu bentuk tindakan yang memuat regulasi yang berkaitan dengan tugas dan tanggung jawab serta wewenang yang dipakai sebagai pijakan dalam pelaksaan pelayanan yang diberikan kepada masyarakat. Dalam pelayanan jugan memuat prosedur atau metode tertentu diberikan oleh pelaksana pelayanan kepada masyarakat dengan tujuan sebagai pemenuhan atas apa yang dibutuhkan oleh masyarakat.

Konsep Pelayanan Publik

Goetsch dan Davis dalam Hardiyansyah (2011:36), menyatakan bahwa: kualitas pelayanan adalah sesuatu yang berhubungan dengan terpenuhinya harapan/kebutuhan pelanggan, dimana pelayanan dikatakan berkualitas apabila dapat menyediakan produk dan jasa (pelayanan) sesuai dengan kebutuhan dan harapan pelanggan. Dalam hal ini, kualitas pada dasarnya terkait dengan pelayanan yang baik, yaitu sikap atau cara karyawan dalam melayani pelanggan atau masyarakat secara memuaskan. Pendapat Pasuraman (2001:165) kualitas pelayanan adalah suatu pengertian yang kompleks tentang mutu, tentang memuaskan atau tidak memuaskan. Pendapat ini mengandung makna bahwa apabila pelayan yang diharapkan harus sama dengan yang dirasakan, sebaliknya bahwa pelayanan dapat dikatakan tidak memenuhi harapan manakala pelayanan yang didapatkan itu tidak sesuai harapan dan juga yang tidak kalah penting untuk memenuhi pelayanan yang memuaskan diperlukan standar pelayanan publik.

Zeithaml at all (1990) dalam hardiyansyah (2011:41) menyederhanakan menjadi lima dimensi, yaitu dimensi SERVQUAL (kualitas pelayanan) sebagai berikut: (1) Tangibles. Appearance of physical facilities, equipment, personnel, and communication materials; (2) Reliability. Ability to perform the promised service dependably and accurately; (3) Responsiveness. Willingness to help customers and provide prompt service; (4) Assurance. Knowledge and courtesy of employees and their ability to convey trust and confidence; and (5) Empathy. The firm provides care and individualized attention to its customers.

Artinya bahwa untuk melihat skala SERVQUAL maka didasarkan pada lima dimensi kualitas yaitu: (tangible, reliability, responsiveness, assurance, dan empathy).

Wujud penampilan (tangibles), meliputi bagian-bagian pelayanan yang bersifat nyata, yaitu penampilan fasisilitas fisik, peralatan, kariawan, dan peralatan komunikasi.

Kehandalan (realibility) kemampuan perusahaan memberikan kualitas pelayanan yang dijanjikan secara akurat.

Daya tangkap (responsiveness), kesediaan perusahaan dalam membantu pelanggan serta memberikan usaha pelayananyang cepat dan tanggap.

Jaminan atau kepastian (asurance), tingkat pengetahuan dan kerahtamaan yang harus dimiliki kariawan disamping kemampuan mereka dalam menanamkan kepercayaan kepada pelanggan. 
Metode Penelitian

Adapun metode yang dipakai dalam penelitian ini yakni menggunakan pendekatan kualitatif dengan metode deskriptif. Di mana dengan metode dan pendekatan ini suatu penelitian yang bertujuan untuk mendiskripsikan secara riil dan kongkrit sesuai dengan apa yang ditemukan dilapangan kemudian menganalisisnya dengan objektif berkaitan dengan pelayanan dan faktor yang mempengaruhi pembuatan e-KTP di Dinas Kependudukan dan Pencatatan Sipil Kota Ternate.

Teknik Pemilihan Informan

Pemilihan informasi dalam penelitian ini di lakukan dengan tehnik purposif sampling. Dimana penelitian ini tidak dilakukan pada seluruh populasi, melainkan pada target-target tertentu. Husaini dan Purnomo (2004:47) menjelaskan bahwa Teknik purposive (bertujuan) digunakan apabila angota yang dipilih secara khusus berdasarkan tujuan pertimbangan memilih informasi dilakukan berdasarkan kategori, yaitu: (1) memiliki kemampuan intelektual untuk memberikan informasi yang di butuhkan, (2) memiliki dan perhatian terhadap objek yang diteliti, (3) memiliki kesangupan untuk menerima peneliti, dan (4) adanya keberanian untuk memberikan informasi yang benar. Alasan pemilihan Teknik ini adalah pertama tingkat kemudahan dalam menjangkau dan mengobservasinya.

Teknik Pengumpulan Data

Instrumen penelitian ini adalah peneliti sendiri dengan menggunakan tehnik pengumpulan data sebagai berikut:

Wawancara (interview)

Pengumpulan data dengan tehnik wawancara digunakan dalam penelitian ini karena mempunyai beberapa kelebihan antara lain: dapat bersifat fleksibel, tingkat pengembalian jawaban lebih tinggi, reaksi responden dalam menjawab pertanyaan dapat diawasi, urutan dan susunan pertanyaan dapat dikontrol oleh interviuw dapat mencatat jawaban secara spontan, dan interviuw dapat langsung mengontrol saat responden menjawab pertanyaan.

\section{Observasi (observation)}

Teknik ini memperoleh fakta-fakta yang tampak dan memperoleh dimensi-dimensi baru untuk pemahaman konteks maupun fenomena yang diteliti menyangkut dengan kualitas pelayanan dan faktor yang mempengaruhi pembuatan e-KTP di Dinas Kependudukan dan Pencatatan Sipil Kota Ternate.

Dokumentasi (documentation)

Teknik ini digunakan untuk menulusuri datadata dekumentatif yang ada di lokasi penelitian. Pengumpulan data sepenuhnya dilakukan sebagai instrumen penelitian dengan dilengkapi alat bantu penelitian berupa dokumen: wawancara, observasi, dan buku catatan lapangan.

Pada tahapan ini akan dilakukan observasi terhadap situasi pelayan e-KTP di Dinas Kependudukan dan Pencatatan Sipil Kota Ternate dan wawancara dengan para informan yang telah ditentukan. Adapun wawancara yang dilakukan akan berdasarkan pada pertanyaan-pertanyaan sesui dengan teori dari Zeinthalm.

Teknik Aanlisi Data

Terkait denga kualitas pelayanan publik dalam pembuatan e-KTP oleh Dinas Kependudukan dan Pencatatan Sipilkota Ternate dan faktor pendukung dan penghambat dalam pelaksanaan pelayanan e-KTP oleh Dinas Kependudukan dan Pencatatan Sipilkota Ternate. Adapun prosedurnya adalah sebagai berikut:

Pengumpulan data

Tahap ini dimana semua data sesuai dengan hasil observasi dan wawancara dilapangan dicatat dengan objektif.

Reduksi data

Proses pemilihan, pemusatan, pengabstrakan, dan transformasi data mentah yang ada berdasarkan catatan-catatan tertulis di lapangan. Miles, B. Matthew \& A. Michael Hubar (1992:17).

Sajian data.

Sekumpulan informasi yang tersusun yang memberi kemungkinan adanya penarikan kesimpulan dan pengambilan tindakan. Miles, B. Matthew \& A. Michael Hubar (1992:17).

Kesimpulan/verifikasi data.

Pada tahapan ini dimana berdasarkan pada reduksi data dan sajian data yang merupakan jawaban atas permasalahan yang diangkat. 


\section{HASIL PENELITIAN DAN PEMBAHASAN}

Untuk mengukur kualitas pelayanan publik pembuatan e-KTP yang ada di Dinas Kependudukan dan Pencatatan Sipil Kota Ternate, Penulis menggunakan theori Zeithaml at all (1990:42) yang mengindikasikan lima indikator kualitas pelayanan. Diantaranya liam indikator yaitu: Wujud Penampilan (Tangible), Kahandalan (Realibility), Daya Tanggap (Responsiveness), Jaminan/Kepastian (Assurance), dan Kepedulian (Empathy).

Lima pendekatan tersebut digunakan untuk mengukur kepuasan publik sebagai objek pelayanan, karena puas tidaknya dan baik buruknya kualitas pelayanan yang diberikan oleh aparatur pemerintahan tergantung pada bagaimana publik merasakan sentuhan pelayanan yang dipersembahkan, apakah pelayanan yang diberikan sesuai dengan yang mereka harapkan ataukah tidak. Berikut ini Penulis akan menguraikan lima dimensi yang dijadikan sebagai tolak ukur kualitas pelayanan e-KTP oleh Dinas Kependudukan dan Pencatatan Sipil Kota Ternate:

Tangible (wujud)

Berdasarkan hasil penelitian melalui wawancara serta di dukung dengan observasi dan dokumentasi bahwa jika dilihat dari indikator tangible atau wujud fisik kualitas pelayanan publik pembuatan e- KTP yang ada di Dinas Kependudukan dan Pencatatan Sipil Kota Ternate dari segi fasilitas dan bangunan masih dikatakan belum layak sebagai layanan publik. DISDUKCAPIL Kota Ternate memiliki keterbatasan fasilitas fisik yang signifikan berupa kondisi bangunan yang terbilang kecil sehingga tidak bisa menampung fasilitas penunjang lainnya berupa tempat duduk untuk para pengguna layanan dalam melakukan kepengurasan e-KTP dan kepengurusan lainnya. Kondisi ini memicu rasa ketidaknyamanan para penggunan layanan yang tidak mendapatkan tempat duduk dalam proses antrian untuk menuggu giliran dalam proses pengambilan nomor dan verifikasi berkas pembuatan e-KTP. Sedangkan dari segi kerapihan pakaian yang dikenakan para petugas saat bertugas sudah cukup baik namun masih ada beberapa petugas yang masih sergam misalnya warna hijab yang dikenakan petugas perumpuan masih terlihat belum seragam sehingga terlihat kurang rapih. Sedangakan dari wujud ketersedian fasiltas sarana sebagai alat penunjang pembuatan e KTP, Berdasarkan hasil observasi bahwa untuk memudahkan pelayanan e-KTP oleh DISDUKCAPIL Kota Ternate, maka alat-alat bantu yang digunakan adalah pengeras suara untuk pemanggilan nomor antrian, computer yang digunakan untuk mengecek dan mengentri data para pengguna layanan, alat pngecekan sidik jari, alat untuk tanda tangan elektronik bagi pengguna layanan yang mau merubah tanda tangan yang sebelumnya, alat percetakan yang ada di bagian dalam ruangan operator percetakan dan satu unit computer beserta perangkat kerasnya.

Ketersediaan alat bantu dalam pelayanan e-KTP oleh disdukcapil ini terbilang sudah baik namun perlu adanya penambahan alat karena dengan alat bantu yang ada tersebut membuat para masih kewalahan dalam memberikan pelayanan percetakan e-KTP. Dengan adanya dua computer yang dipakai dalam pelayanan eKTP peniliti merasa belum cukup dengan jumlah pengguna layanan e-KTP yang ada.

\section{Dimensi Reliability (Kehandalan)}

Dimensi Reliability dalam upaya mengetahui kualitas pelayanan e-KTP di Kantor Dinas Kependudukan dan Pencatatan Sipil Kota Ternate dapat diukur melalui kecermatan pegawai dalam melayani pengguna layanan, adanya standar pelayanan e-KTP, dan bagaimana kemampuan pegawai dalam menggunakan alat bantu.

Berdasarkan hasil penelitian melalui wawancara dan observasi dilapangan dapat diketahui bahwa jka dilihat dari dimensi kehandalan bahwa kemampuan yang dimilliki oleh petugas pelayanan e-KTP pada DISDUKCAPIL Kota Ternate maka menjadikan pelayanan e-KTP yang diberikan itu dikatakan berkualitas. Hanya saja menurut hasil pengamatan bahwa terjadi sedikit keterlambatan dalam proses percetakan eKTP dikarenakan terbatasnya jumlah pelaksanan yang menangani penerbitan e-KTP. Menanggapi masalah ini seharusnya adanya penambahan jumlah petugas pelayanan e-KTP supaya pelayanan yang diberikan bisa lebih maksimal. Selain itu Sumber Daya Manusia (SDM) oleh petugas dalam penggunaan alat bantu pelayanan tersebut sudah sejauh pengamatan Penulis bahwa mereka sudah menguasai dengan baik. Hal itu dikarenakan para petugas terlihat berpengalaman terhadap hal itu karena pekerjaan yang mereka lakoni itu sudah cukup lama. Selain itu juga DISDUKCAPIL Kota Ternate sudah memiliki SDM yang mumpuni dalam melakukan pelayanan e-KTP, sehingga dalam melayani pengguna layanan e-KTP para petugas terlihat serius dan cepat dalam pelayanan e-KTP dengan menggunakan alat bantu. Kondisi ini kemudian memunculkan kepuasan oleh para pengguna layanan e-KTP dengan tidak adanya keluhan pada dimensi realibility.

\section{Dimensi Responsiveness (Ketanggapan)}

Dimensi responsiveness sangat penting bagi sebuah layanan publik karena dapat menetukan kepuasan bagi pengguna layanan. Untuk mengukur dimensi responsiveness untuk mengetahui kualitas pelayanan terkaid e-KTP oleh DISDUKCAPIL Kota Ternate dapat diukur melalu respon terhadap keluhan pengguna 
layanan, dan kecepatan dan ketepatan dalam melakukan proses pelayana e-KTP. Berdasarkan hasil penelitian melalui wawancara dan observasi bahwa serta didukung dengan dokumentasi yang ada maka pada dimensi Responsiviness menyangkut dengan respon pegawai terhadap pengguna layanan pada DISDUKCAPIL Kota Ternate maka didapatkan bahwa para petugas pelayanan e-KTP sudah melaksanakan prinsip ini dengan baik. Hal ini juga dapat dilihat dari bentuk perhatian oleh petugas pelayanan dalam menanggapi keluhan para pengguna layanan dengan mengedepankan kepentingan pengguna layanan. dari aspek kecepatan dan ketepatan secara umum untuk semua pengguna layanan maka pelayanan e-KTP terbilang lambat karena DISDUKCAPIL Kota Ternate hanya memiliki satu alat percetakan yang dipakai. Kecepatan dan ketepatan dalam pelayanan e-KTP juga terkendala dengan seringnya terjadi gangguan jaringan Internet sehingga sering kali menunda proses percetakan eKTP. Gangguan ini berupa tidak terkoneksinya jarinngan internet yang baik (gangguan server) sehingga putusnya jaringan komunikasi data oleh Pemerintah Pusat kepada DISDUKCAPIL Kota Ternate.

\section{Dimensi Jaminan (Assurance)}

Dalam melaksanakan tugas pelayanan penerebitan e-KTP, DISDUKCAPIL kota Ternate berpedoman pada Standar Operasional Prosedur (SOP) yang telah ada. Pada SOP penerbitan e-KTP telah memuat ketentuan tentang dimensi ketepatan waktu dan biaya dalam pelayanan

Dalam melaksanakan tugas pelayanan penerebitan e-KTP, DISDUKCAPIL kota Ternate berpedoman pada Standar Operasional Prosedur (SOP) yang telah ada. Pada SOP penerbitan e-KTP telah memuat ketentuan tentang dimensi ketepatan waktu dan biaya dalam pelayanan. Pada pembahasan ini mencoba melihat representasi dari SOP yang ada dengan implementasi terkait dengan pelayanan e-KTP

Dari hasil observasi didapatkan bahwa proses pelayanan e-KTP oleh DISDUKCAPIL Kota Ternate tidak dipungut biaya, sama halnya dengan wawancara terhadap para informen sebagai pengguna layanan bahwa dalam melakukan pengurusan e-KTP tidak ada biaya yang mereka keluarkan, serta juga dokumentasi terkait transparansi kepada masyarakat bahwa semua pengurusan oleh DISDUKCAPIL bebas biaya.

Berdasarkan hasil observasi dan wawancara serta didukung oleh dokumen yang didapatkan bahwa kualitas pelayanan e-KTP pada dimensi assurance terbilang sudah baik belum maksimal. hal ini ditandai dengan proses ketepatan waktu pelayanan dalam penyelesaian prodak e-KTP oleh DISDUKCAPIL Kota Ternate tidak sesuai dengan Standar Operasional Prosedur (SOP). SOP telah ditentukan mulai dari proses pendaftaran oleh pemohon hingga proses percetakan yaitu dengan jangka waktu 14 hari sejak pendaftaran di DISDUKCAPIL

\section{Dimensi Empati (empathy)}

Untuk mengukur kualitas pelayana e-KTP pada DISDUKCAPIL Kota Ternate pada dimensi empathy, Penulis melihat dari beberapa aspek yaitu tingkat keramahan dan kesopanan petugas dalam pelayanan eKTP, apakah petugas pelayanan e-KTP sudah mendahulukan kepentingan pengguna layanan, apakah ada praktek diskriminatif pelayanan e-KTP atau tidak.

Berdasarkan hasil penelitian yang didukung observasi dan dokumentasi bahwa kualitas pelayanan eKTP pada dimensi emphaty dapat dikatakan sudah baik namun belum maksimal. DISDUKCAPIL kota Ternate telah berhasil mempersembahkan pelayanan yang baik pada aspek keramahan dan kesopanan petugas pelayanan e-KTP, dan juga pada aspek mendahulukan kepentingan pengguna layanan. Hanya saja yang menjadikan pelayanan e-KTP menjadi buruk adalah masih dilakukannya praktek diskriminatif dengan mendahulukan kepentingan pengguna layanan yang dikena.

\section{SIMPULAN}

Dari pemaparan pada Bab sebelumnya maka dapat ditarik kesimpulan bahwa kualitas pelayanan e-KTP pada Dinas Kependudukan dan Pencatatan Sipil Kota Ternate berdasrkan teori yaitu denga lima dimensi untuk mengukur kulaitas palyanan public yang dikemukakan oleh Zeithalm et all (1992:37) yang diantaranya adalah Dimensi Tangible (Penampilan), Dimensi Realibility (Kehandalan), Dimensi Responsiveness (Daya Tanggap), Dimensi Assurance (Kepastian), dan Dimensi Empathy (Kepedulian), maka disimpulkan bahwa kualitas pelayanan e-KTP oleh DISDUKCAPIL Kota Ternate sudah baik dengan memilki syarat administratif sebagaimana yang disyaratkan oleh UU 25 Tahun 2009 tentang pelayanan publik yaitu adanya standar pelayanan, maklumat pelayanan, fasilitas pendukung dalam pelayanan, mekanisme komplen (jalur pengaduan), serta petugas pelyanan yang handal dalam melakukan pelayanan e-KTP. Hanya saja dapat dikatakan belum maksimal karena ditandai dengan pendapat sebagian Informan tentang ketersediaan infrastruktur (bangunan fisik) yang dipunyai oleh DISDUKCAPIL Kota Ternate yang tidak bisa menampung rasio pengguna layanan yang datang, ketersediaan fasilitas penunjang yang masih minim berupa kurangnya tempat duduk yang disediakan karena ruangan yang sempit, tidak maksimalnya pendingin ruangan karena hanya ada satu mesin 
pendingin ruangan parkiran kendaraan.

Pelayanan e-KTP juga terkendala dengan kedisiplinan petugas pelayanan yang kadang-kadang terlambat datang ke kantor sehingga menunda proses pelayanan e-KTP dalam beberapa menit, juga yang lainnya adalah kekosongan blangko e-KTP dengan kurun waktu lima bulan sehingga memunculkan terhambatnya percetakan e-KTP, skurangnya kesadaran msyarakat untuk segera mendatangi DISDUKCAPIL Kota Ternate dalam melakukan percetakan e-KTP tanpa menunggu moment-moment tertentu, selain itu juga yang menjadi kendala petugas pelayanan e-KTP dalam penerbitan e-KTP pada DISDUKCAPIL Kota Ternate adalah sering terjadinya gangguan server oleh pemerintah pusat pada pukul 10.00-12.00 WIT pada waktu-waktu tertentu yang kemudian juga membuat pelayanan e-KTP menjadi tidak maksimal. oleh sebab itu perlu ada upaya untuk meminimalisir masalah-masalah yang sering muncul dalam pelayanan e-KTP oleh DISDUKCAPIL Kota Ternate.

\section{Saran}

Berdasarkan kesimpulan yang telah diuraikan diatas maka saran dari Penulis adalah:

1. Perlunya pengusulan kepada pemerintah kota ternate untuk melakukan perenovasian terhadap bangunan yang dimilki.

2. Meningkatkan kedisiplinan kepada petugas pelayanan.

3. Memperbahrui fasilitas-fasilitas pendukung yang tersedia berupa tempat duduk untuk para pengunjung, melakukan penambahan mesin pendingin ruangan, serta perlu diadakannya jalur dan tempat khusus bagi penyandang Disabilitas.

4. Mengusulkan kepada Mentri Dalam Negeri untuk menambah alat percetakan e-KTP

5. Melakukan sosialisasi terhadap masyarakat supaya memilki kesadaran untuk mensukseskan program Nasional e-KTP.

6. Mengusulkan kepada mendagri untuk memberikan sanksi administrativ kepada masyarakat yang belum melakukan perekaman e-KTP.

\section{Daftar Pustaka}

Abdurrahman, O. (1995) "Dasatr-Dasar Publik Relation”. PT Citra Aditya Bakti. Bandung.

Hardiyansyah (2011), "Kualitas Pelayanan PublikKonsep, Dimensi, Indikator, Dan Implementasi”, Gava
Media. Cetakan Ke 1. Yogyakarta. 2011.

Inu, K S, (1099), "Ilmu Administrasi Publik". PT. Rineka Cipta, Jakarta.

Imailda R (2008), Evalwasi pemberdayaan masyarakat melalui pembentukan warga madani di pasar minggu jakarat selatan. Tesis, Jakarta.

Parasuraman, A.Valerie (2001), (Diterjemahkan Oleh Sutanto). "Delivering Qulity Service". The Free Pers, New York.

Romhan,AA (2010), "Revormasi Pelayanan Publik". Cetakan ke dua. Averroes press. Et all. Malang.

Rusli, B. (2004), Pelayanan Publik di Era Reformasi. Dalam www.pikiranrakyat.com edisi 7 Juni 2004.

Sinambela, L.P, (2010), "Revormasi Pelayanan Publik; Teori, Kebijakan, Dan, Implementasi". Cetakan Kelima. PT. Bumi Aksara. Jakarta.

Sugandi SY (2011), “Administrasi Publik Konsep Dan Perkembangan Ilmu Di Indonesia". Graha Ilmu. Yogyakarta.

Sugiyono (2000), "Metode Penelitian Bisnis". CV Alvabeta. Bandung.

UndangUndang No. 24 Tahun 2013 tentang Administrasi Kependudukan.

Ulber S, dan Wirman S (2015) "Desentralisasi Dan Demokrasi Pelayanan Publik "Menuju Pelayanan Pemerintah Daerah Lebih Transparan, Paertisipatif, Dan Akuntabel” IPDN PRESS. Cetakan Pertama. Bandung.

Usman, H (2004) "Metodolo gi penelitian sosial". sinar grafika offset.cetakan kelima. Jakarta.

Zeithalm, V.A, A. Pasuraman, and L.L. Berry (1990), "Delivering Quality Service". New York. The Free Press. 